\title{
The Effect of Audio-Visual Materials on Iranian Second Grade High School Students' Language Achievement
}

\author{
Fatemeh Asadi, Shaban Berimani \\ Department of English Language, Sari Branch, Islamic Azad University, Sari, Iran \\ Email address: \\ asadi.fatemeh1144@yahoo.com (F. Asadi),sh_barimani45@yahoo.com (S. Berimani)
}

To cite this article:

Fatemeh Asadi, Shaban Berimani. The Effect of Audio-Visual Materials on Iranian Second Grade High School Students' Language Achievement. International Journal of Language and Linguistics. Vol. 3, No. 2, 2015, pp. 69-75. doi: 10.11648/j.ij11.20150302.15

\begin{abstract}
The present study investigated the effect of audio -visual materials on Iranian second grade high school students' language achievement. The participants were 80 Iranian female students with the age of 15-16 that were selected from high schools in Savadkooh, north of Iran. The administration of the OPT test and taking the result a homogeneous group of 60 was formed and 20 participants were excluded from the study. Participants were randomly selected into two homogeneous groups each consisting of 30 students. Both of the groups were taught the same materials. The control group received the traditional treatment without the audio-visual materials while the experimental group received the audio-visual materials treatment. Before starting the treatment two similar tests based on high school English text book 2 were prepared by the researcher as the pretest/posttest to find out students language achievement at the beginning and at the end of the study. Analysis of this study and the results in the posttest showed significant differences between the two groups. Also participants in experimental group received and answered the pre-test and post-test motivation questionnaire to find out the effect of audio-visual materials on improving students' motivation. The results indicated that the students in the experimental group performed better than the students in the control group in their language achievement. So, it was concluded that the role of audio-visual materials in teaching high school English textbook2 to students led to a higher level of improvement in students' motivation and language achievement.
\end{abstract}

Keywords: Audio-Visual Materials, High School English Textbook2, Language Achievement, Motivation

\section{Introduction}

Language learning is a complex process which requires the language teacher to use the best materials in his/her classroom. So, teachers need new technologies relate to the teaching /learning process. Nowadays, it is true that audio-visual materials are a great help in stimulating and facilitating the teaching/ learning of a foreign language. According to Cakir (2006), audio-visual materials can encourage foreign language learning and they help in stimulating and facilitating learning English. It makes learning dynamic, experience, and more realistic, it has developed since 1920 s by drawing on new technologies of communication. Audio-visual materials consist of two words, audio referring to those materials which can be heard and visual referring to those materials which can be seen. Based on Hemei (1997), students like audio-visual materials because they are interesting, challenging, and motivating to watch and listen. Based on Gredler (2001) Motivation is the trait that moves humans to do or not to do something. Students' motivation is a vital element that is necessary for quality of education. Bernaus and Gardner (2008) alerted more on the relations between teachers teaching strategies, students' motivation and language achievement used in the English foreign class. Achievement in a second or foreign language has been seen as knowledge about the structure of the language such as grammar, pronunciation, vocabulary, or in terms of proficiency in the four basic skills listening, speaking, reading and writing. English language learning as a foreign language in Iran is taught since junior school and most of Iranian students still have difficulties to communicate after receiving English language education. Text books play a very basic role in English as a foreign or as a second language in the classroom. Nunan (1999) argues that a textbook is the main part of any instructional syllabus and it is difficult to imagine a class without it. Current English textbook2" in high schools of Iran have been used for about two decades .There is little use of pictures and illustrations to make them attractive enough for the students, and they are not clear enough for the students to completely understand what 
they should do. The book lacks of listening comprehensions. The main purpose of this research is to demonstrate the effect of audio-visual materials on the Iranian high school students' language achievement and what impact these materials on improving on high school students' motivation. It can be extended and practical for other schools and institutes or teachers, and offer pedagogical applications for teachers to have a better view on using audio-visual materials as video, projector and power point.

This study showed: First, audio-visual materials can be a potential solution for the learners' language achievement problems. Second, this study can offer a very helpful and potential solution for the learners' listening and speaking problems because exposure of the learners to audio-visual materials can improve students' language achievement. Third, this study considered to overcome the difficulty with language achievement among Iranian second grade high school students, and discovered the effectiveness of applying audio-visual materials in improving students' motivation and language achievement. This study suggests the policy maker of education to consider the needs of the new generation in the technology-oriented era and use the texts and audio-visual materials related to today interests, needs, and concerns.

\section{Review of the Related Literature}

\subsection{Language Achievement}

Based on Bachman and palmer (1996), language achievement is defined as a learner's gain in a second or foreign language as a result or learnt after a period of instruction .It refers to progress in learning the course content, and may be measured through the use of Achievement tests. Based on Jafarpour (1992), teaching without testing the outcome of teaching would be useless. Teachers want to evaluate their students' achievement to know how much their students have learned during the course or how successful they themselves have been in teaching after a period of instruction.

\subsection{Motivation}

In English language acquisition, students' motivation, attitude, identity and understanding of language learning have been emphasized, and play important roles in language learning. According to Gardner (1983), second language learners' attitudes towards English language learning and towards the entire language world influenced learners' level of motivation. During learning a language, learners' attitudes or motivation may be directly determined by their perceptions of language teaching and learning. Miller, (2009) Motivation is the other major affective factors to second language acquisition. Harmer (2001) defines motivation as ' some kind of drive which pushes someone to do things in order to get something'. Many students are extrinsically motivated. That is, they just want to learn a language so as to get some aims, for instance succeeding in an examination, getting their driving, or even having training abroad in a highly regarded university.
In contrast to intrinsically motivated students who just want for learning a language. When it was described, extrinsic motivation is caused by many external factors while intrinsic motivation comes from within the individual. According to Gardner (1985), to be motivated, the learner needs to have something to look forward to, a purpose related to goal or objective.

\subsection{Using Audio-Visual Materials and Different Language Methodologies}

Incorporating technology challenges students and encourages them to develop their own learning strategies and proceed at their own pace (Maftoon et al., 2012). It can also improve autonomy in language learning on the part of the learners (Hamidi \& Montazeri, 2014). Different language teaching-learning theories and methods protect the concept of using audio-visual materials in language teaching. Freeman (2000) states Communicative Language Teaching (CLT) is one of the popular language teaching approaches which aimed the practical use of language in everyday communication and the use of authentic materials is highly emphasized. Teachers are encouraged to use different audio-visual materials in a CLT class. There are wide ranges of use of the pictures and videos in the classroom to make the classroom motivating and authentic. The Direct Method which emphasizes teachers uses different visual materials such as pictures and posters in the classroom. As they cannot use the L1 to explain something, using visual materials is the major plan for them. (Freeman, 2000). The Principles of Silent Way was that, learning is facilitated if the learner discovers or creates rather than remembers and repeats what is to be learned, learning is facilitated by associated physical objects and problem solving including the materials to be learned. In this method, use of visual materials facilitated the teaching and learning process. Teachers use sound-color chart and color rod to teach the target language. (Richards \& Rodgers, 1986). Freeman (2000) noted that suggestopedia is a language teaching method that highly supports the use of audio-visual aids in teaching language. The most conspicuous characteristics of suggestopedia are the furniture, design and form of the classroom, the use of music and the authoritative behavior of the teacher (Richards \& Rodgers, 1986).

Gruba (1997) did a research to see the effect of video materials which he explains as the combination of sound and dynamic visual elements and multimedia applications on the assessment of listening comprehension. In his opinion, using video media in evaluating listening comprehension makes its more challenging. Mayer (2003) investigated the role of visual materials in second language learning among English as a Foreign Language (EFL) students using pictorial stimuli corresponding with text, and discovered that the use of pictures does help in second language acquisition. De Bot, Lowie, and Verspoor (2005) suggested that students' positive attitudes towards language learning affect the target language learning. Based on Mutar(2009), the use of power point slides help the teacher to send their lectures in dynamic ways which becomes interesting to the learners. Potosi et al. (2009) did a 
research to see the impact of video on listening skill and towards video. The mission of the program was to prepare professional English teachers to increase the educative level of the region in the learning of English as a foreign language. They consider video materials as authentic which provide real situations, intonations, hesitations, rephrasing and other authentic features of native speakers' speech which give to easier understanding of pronunciation. It is concluded that implementing video material to advance listening skill has important effect on listening comprehension, awareness of English language pronunciation, stress and intonation. Also, videos promoted learners` motivation.

Mutar (2009) discussed the similar results of the using power point slides in classroom to give lecture. He stated that the use of power point slides help the teachers to deliver their lectures in dynamic ways which becomes interesting to the learners. Choi and Johnson (2010) did a research to see whether context-based video instructions based on constructivist approach can promote learning or not. They compared video-based instruction with traditional text-based one in an online context-based lesson. They considered learners' motivation and they concluded that video-based instruction had more effect and had potential impact on learners ' motivation.

Erfani, Iranmehr and Davari (2011) did a study on the effect of visualization on comprehension of reading texts. Their research was based on the plan that if a person can build mental images while he is reading, he can have a better understanding of what he is reading. They stated that the ability to build mental images while reading can be a good and effective strategy which learners must obtain it.

Dehghani and Jowkar (2012) also did a study. Their study is planned to facilitate the process of listening comprehension in EFL environments. Fifty-six Iranian undergraduate students were chosen for this study, and then they were divided randomly into control and experimental groups. The gathered data showed the advantage of experimental group over the control group. The use of video texts helps them in processing and comprehending aural input. Safarali and Hamidi (2012) did a study on the impact of videos presenting speakers' gestures and facial clues on Iranian EFL learners' listening comprehension. They conclude that using videos presenting speakers' gesture and facial clues has a significant effect on the EFL learners' listening comprehension.

Ismaili (2013) did a different study to observe the effect of movies to make learners to be more involved in reading activities. The study aimed to explain and analyze the effectiveness of using movies on improvement of language competence and performance of learners in academic settings. Also the study aimed to examine whether movies may provide as a bridge between learning skill and language objectives or performances of learners. Through the questionnaires the learners`attitude towards movie-based teaching and learning were investigated. Naraghizadeh and Barimani (2013) examined a research to see the effect of Call on the vocabulary learning of Iranian EFL learners. Their study was concluded to consider the effectiveness of call on Iranian EFL learners' vocabulary learning as compared to those students receiving traditional instruction using the printed text materials. The results of descriptive statistics showed that the group who received Computer Assisted Language Learning was more significant in this study. Mathew and Alidmat (2013) considered a study on the usefulness of audio-visual aids in ELT in Saudi Arabia context. They found how the use of audio visual materials helps the language teacher in EFL classroom at undergraduate level. The result of their study indicates that using audio-visual materials in language teaching is helpful for both the teachers and the students.

The purpose of this study was to investigate the effect of Audio and Visual Materials on Iranian second grade high school students' language achievement. The present study aimed at answering the following question: Do Audio-Visual Materials have any effect on Iranian Second Grade high school Students' Language achievement? Do Audio-visual Materials have any effect on improving Iranian second grade high school students' motivation?

\section{Methodology}

This is a quantitative research, which relies on the high school English textbook "English Book 2" The aim of the present study was to investigate the effect of audio-visual materials on Iranian second grade high school students' language achievement. This chapter was a description of the participants, the instruments used for data collection, the applied procedures, and the way in which data analysis was done in the present study.

\subsection{Population and Sampling}

Two public schools were purposefully selected from the educational system in Savadkooh, north of Iran. Participants were selected through convenience sampling method. In addition, the schools were prepared with audio-visual materials and computer system . The sample of study consisted of 80 Iranian second grade high school female students. After the administration of the OPT test of English language proficiency and taking the result into account, a homogenous group of 60 was formed and 20 participants were excluded from the study as outliers. They were divided randomly into 2 groups, as experimental and control group.

\subsection{Instruments and Materials}

To implement this study successfully, the researcher has developed several types of instruments, such as OPT-test, Language achievement-test, and motivational questionnaire. To conduct the present study the following instruments were employed:

1. An Oxford Placement Test (OPT)

2. A Pre-Test/ Post- Test (based on Iranian high school English Textbook

3. A Pre-Test/Post-Test Motivation Questionnaire

4. Flash Cards

5. Pictures 


\section{Power Points \\ 7. Smart Board \\ 8. Video Projected Aids}

\subsection{Procedure}

The design of this research is an experimental with pr-test and post-test procedure. The operational-phase of the study took three months, including using appropriate audio-visual materials for teaching in the classroom, making appropriate pre-test and post-test based on English high school text book 2, piloting the selected test. Both of two groups were taught the same materials based on the curriculum and in the same months. After the administration of the OPT test of English language proficiency and taking the result, a homogenous group of 60 was formed, and the participants were divided into 2 groups, and each group was randomly assigned ,thirty students were taken for the experimental group and thirty students for the control group, too. The different treatments were applied in two groups. The experimental group was taught by using audio-visual materials and the control group was taught traditionally means without audio-visual materials. The researcher also did the motivation test to investigate whether the audio-visual materials have any effect on improving Iranian second grade high school students' motivation. (Clement, Dornyei, \& Noels, 1994). The content validity of this test was evaluated by three experts who were PHD holders of applied linguistics with more than five years of teaching experiences.

Table 3.1. Test/Retest Reliability of the Language Achievement Question

\begin{tabular}{lll}
\hline Reliability Statistics & & \\
\hline Cronbach's Alpha & Cronbach's Alpha Based on Standardized Items & N of Items \\
\hline .933 & .936 & 2 \\
\hline
\end{tabular}

According to table 3.1 above, the reliability of the language achievement test made by the researcher was .933 which shows high reliability. This test was given to the students two times in one week interval.

\section{Results}

This chapter aims to provide the results of data analysis, results of the OPT used as homogeneity test, analysis of the first research question, test of normality for the achievement scores, analysis of the second research question. This chapter presents related data analysis to the following research questions:

RQ1-Do Audio-Visual Materials have any effect on Iranian Second Grade high school Students' Language achievement?

RQ2-Do Audio-visual Materials have any effect on improving Iranian second grade high school students' motivation?
Based on the aforementioned research questions the following null hypotheses were suggested:

H01: Audio and visual materials do not have any effect on Iranian second grade high school students' language achievement.

H02: Audio and visual materials do not have any effect on improving students' motivation.

Before presenting the analysis for research question, the result of the Oxford Placement Test used as the homogeneity test is shown.

\subsection{Result of the OPT Used as Homogeneity Test}

In order to have homogenized participants in terms of their general English language proficiency, the Oxford Placement Test (OPT) was administered. The descriptive analysis for the OPT test is displayed in the following table.

Table 4.1. The Descriptive Statistics of the OPT Score

\begin{tabular}{llllll}
\hline Descriptive Statistics & & & & & \\
\hline & N & Minimum & Maximum & Mean & Std. Deviation \\
\hline OPT & 80 & 14.00 & 38.00 & 26.5500 & 5.61621 \\
Valid N (listwise) & 80 & & & & \\
\hline
\end{tabular}

Out of the eighty participants, sixty were considered as homogenous members based on one standard deviation above and below the mean $(+/$ 5.61). Figure 4.1 below shows the histogram with normal curve for the OPT test.

In order to show that there was no significant difference between the learners in the control and experimental groups, the independent $\mathrm{t}$ - test which shows the mean score differences between two groups was performed. The results are presented below.

Table 4.2. Independent T-test for the Comparison of Groups before Treatment

\begin{tabular}{lllllllll}
\hline & & \multicolumn{2}{l}{ Levene's Test for Equality of Variances } & \multicolumn{2}{c}{ t-test for Equality of Means } \\
\cline { 3 - 9 } & & F & Sig. & t & df & $\begin{array}{l}\text { Sig. } \\
\text { (2-tailed) }\end{array}$ & $\begin{array}{l}\text { Mean } \\
\text { Difference }\end{array}$ & $\begin{array}{l}\text { Std. Error } \\
\text { Difference }\end{array}$ \\
\hline \multirow{2}{*}{$\begin{array}{l}\text { Homogenized } \\
\text { OPT }\end{array}$} & $\begin{array}{l}\text { Equal variances assumed } \\
\text { Equal variances not } \\
\text { assumed }\end{array}$ & .414 & .522 & .067 & 58 & .947 & .06667 & .99570 \\
\hline
\end{tabular}


As table 4.2 above shows, the control and experimental groups were homogeneous in terms of language proficiency $(\mathrm{t}$ $(58)=.067, \mathrm{p}>.05)$.

\subsection{Analysis of the First Research Question}

The first research question of this study is as follow:
RQ1: Do Audio-Visual Materials have any effect on Iranian Second Grade high school Students' Language achievement?

In order to show that the two groups had no significant difference on the pretest of language achievement, the control and experimental groups were compared on their pretests. The following table shows the normality test.

Table 4.3. Result of Normality Test for Pretest Scores

\begin{tabular}{|c|c|c|c|c|c|c|}
\hline \multicolumn{7}{|c|}{ Tests of Normality } \\
\hline & \multicolumn{3}{|c|}{ Kolmogorov-Smirnov } & \multicolumn{3}{|c|}{ Shapiro-Wilk } \\
\hline & Statistic & df & Sig. & Statistic & df & Sig. \\
\hline Cont Pretest & .101 & 30 & $.200^{*}$ & .953 & 30 & .208 \\
\hline Exp Pretest & .123 & 30 & $.200^{*}$ & .932 & 30 & .056 \\
\hline
\end{tabular}

a. Lilliefors Significance Correction

*. This is a lower bound of the true significance.

As it can be seen in table 4.3 above, the data is normally distributed for the two sets of pretest scores $(\mathrm{p}>.05)$. Therefore,

the independent t-test was used for pretest comparison.

Table 4.4. Result Independent T-test for Pretest Comparison of Control and Experimental Groups

\begin{tabular}{|c|c|c|c|c|c|c|c|c|}
\hline \multicolumn{9}{|c|}{ Independent Samples Test } \\
\hline & & \multicolumn{2}{|c|}{$\begin{array}{l}\text { Levene's Test for } \\
\text { Equality of Variances }\end{array}$} & \multicolumn{5}{|c|}{ t-test for Equality of Means } \\
\hline & & $\mathbf{F}$ & Sig. & $\mathbf{t}$ & df & Sig. (2-tailed) & Mean Difference & $\begin{array}{l}\text { Std. Error } \\
\text { Difference }\end{array}$ \\
\hline \multirow[b]{2}{*}{ ScoresPretest } & Equal variances assumed & 1.020 & .317 & .418 & 52 & .678 & .60833 & 1.45592 \\
\hline & $\begin{array}{l}\text { Equal variances not } \\
\text { assumed }\end{array}$ & & & .410 & 44.812 & .684 & .60833 & 1.48539 \\
\hline
\end{tabular}

As table 4.4 above shows, there was not any significant between the pretest scores of control and experimental groups $(\mathrm{p}>.05)$.

In order to run an appropriate test for the posttest comparison, the researcher had to meet one assumptions; normality of data distribution. Table 4.5 below shows the normality test for the achievement scores.

Table 4.5. Test of Normality for the Achievement Scores

\begin{tabular}{|c|c|c|c|c|c|c|}
\hline \multicolumn{7}{|c|}{ Tests of Normality } \\
\hline & \multicolumn{3}{|c|}{ Kolmogorov-Smirnova } & \multicolumn{3}{|c|}{ Shapiro-Wilk } \\
\hline & Statistic & df & Sig. & Statistic & df & Sig. \\
\hline Cont Posttest & .128 & 30 & $.200^{*}$ & .912 & 30 & .017 \\
\hline Exp Posttest & .117 & 30 & $.200^{*}$ & .922 & 30 & .030 \\
\hline
\end{tabular}

a. Lilliefors Significance Correction

*. This is a lower bound of the true significance.

As it can be seen in table 4.5 above, the Sig value of the Shapiro-Wilk Test is lower than .05 for the posttest of control and experimental groups, meaning that the two sets of scores are not normally distributed. Therefore, the best test for mean comparison would be the Mann-Whitney U. Descriptive analysis of data related to the posttest of control and experimental groups is displayed in the following table.

Table 4.6. Descriptive Statistics for the Posttest Data

\begin{tabular}{llllll}
\hline & ConPost & N & Mean & $\begin{array}{l}\text { Std. } \\
\text { Deviation }\end{array}$ & $\begin{array}{l}\text { Std. Error } \\
\text { Mean }\end{array}$ \\
\hline Scpres & Control & 30 & 33.6333 & 5.32712 & .97259 \\
Con Exp & Experimental & 30 & 48.2667 & 7.81216 & 1.42630 \\
\hline
\end{tabular}

As it can be seen in table 4.6 above, the mean and standard deviation for the control and experimental groups are 33.63,
5.32 and 48.26, 7.81 respectively. Table 4.7 below shows the actual result of the Mann-Whitney U test.

Table 4.7. Result of the Mann-Whitney U Test for Posttest Comparison.

\begin{tabular}{ll}
\hline Test Statistics $^{\text {a }}$ & \\
\hline & Scpres Con Exp \\
\hline Mann-Whitney U & 66.000 \\
Wilcoxon W & 531.000 \\
Z & -5.683 \\
Asymp. Sig. (2-tailed) & .000 \\
a. Grouping Variable: ConPost & \\
\hline
\end{tabular}

As it can be seen in table 4.7 above, there was a significant difference between the mean scores of the two groups on the posttest $(\mathrm{U}=66, \mathrm{p}<.05)$. The audio-visual group performed better on posttest than the control group did. Thus, it could be concluded that the null-hypothesis "audio-visual materials 
have no significant effect on improving Iranian second grade high school students' language achievement" was rejected, putting emphasis on the effectiveness of the using audio-visual materials.

\subsection{Analysis of the Second Research Question}

The second research question of this study was as follow:

RQ2: Do Audio-Visual Materials have any effect on improving Iranian Second Grade high school Students' motivation?

In order to run an appropriate test, the researcher had to meet one assumption; normality of data distribution. Table 4.5 below shows the result of the normality test.

Table 4.8. Test of Normality for the Motivation in the Experimental Group

\begin{tabular}{lllllll}
\hline \multicolumn{1}{l}{ Tests of Normality } & \multicolumn{1}{l}{} \\
\hline & \multicolumn{1}{l}{ Kolmogorov-Smirnov ${ }^{\text {a }}$} & \multicolumn{3}{l}{ Shapiro-Wilk } \\
\cline { 2 - 7 } & Statistic & df & Sig. & Statistic & df & Sig. \\
\hline MotivationPre & .114 & 30 & $.200^{*}$ & .967 & 30 & .472 \\
MotivationPost & .106 & 30 & $.200^{*}$ & .933 & 30 & .058 \\
\hline
\end{tabular}

a. Lilliefors Significance Correction

*. This is a lower bound of the true significance.
As it can be seen in table 4.8 above, the Sig value of the Shapiro-Wilk Test is higher than 0.05 for the motivation scores, meaning that the two sets of scores are normally distributed. Therefore, the best test for mean comparison within the experimental group would be the paired t-test. Descriptive analysis of the data related to the motivation of the participants is shown in table 4.9.

Table 4.9. Descriptive Statistics of Motivation

\begin{tabular}{llllll}
\hline & Mean & N & $\begin{array}{l}\text { Std. } \\
\text { Deviation }\end{array}$ & Std. Error Mean \\
\hline Pair & MotivationPre & 141.3333 & 30 & 8.83306 & 1.61269 \\
1 & MotivationPost & 163.8667 & 30 & 11.44020 & 2.08869 \\
\hline
\end{tabular}

As it can be seen in table 4.9 above, the mean and standard deviation for the pre-scores and post-scores of motivation scores are $141.33,8.83$ and $163.86,11.44$ respectively. In the next step, table 4.10 below shows the result of the paired t-test for the final conclusion. The paired t-test was run to compare the mean scores of motivation within the experimental group.

Table 4.10. Result of the Paired T-Test for the Motivation Scores

\begin{tabular}{|c|c|c|c|c|c|c|c|c|c|}
\hline & & \multicolumn{5}{|c|}{ Paired Differences } & \multirow{3}{*}{$\mathbf{t}$} & \multirow{3}{*}{ df } & \multirow{3}{*}{ Sig. (2-tailed) } \\
\hline & & \multirow[t]{2}{*}{ Mean } & \multirow[t]{2}{*}{ Std. Deviation } & \multirow{2}{*}{$\begin{array}{l}\text { Std. Error } \\
\text { Mean }\end{array}$} & \multicolumn{2}{|c|}{$\begin{array}{l}95 \% \text { Confidence Interval of the } \\
\text { Difference }\end{array}$} & & & \\
\hline & & & & & Lower & Upper & & & \\
\hline Pair 1 & $\begin{array}{l}\text { MotivationPre - } \\
\text { MotivationPost }\end{array}$ & 22.53333 & 14.51452 & 2.64998 & -27.95314 & -17.11352 & 8.503 & 29 & .000 \\
\hline
\end{tabular}

As table 4.10 shows, the probability of $t(8.503)$ had the sig of (.000), that is much lower than the significance level of .05 $(\mathrm{t}(29)=8.503, \mathrm{p}<.05)$. Based on the results, it could be concluded that there was a significant difference between the mean scores of the participants before and after treatment in the experimental group. Thus, it could be concluded that the null-hypothesis "audio-visual materials do not have any effect on improving Iranian second grade high school students' motivation" was rejected, putting emphasis on the effectiveness of the audio-visual materials.

\section{Conclusion}

According to the results obtained in this study, foreign language achievement of the students in audio-visual materials group was significantly higher than the students without audio-visual materials group. From the responses to the motivation questions in the questioner, the students in experimental group recognized the value of learning English, especially; they believed that English language learning to be useful not only for academic success and communication with other people internationally, but also for better job chances. Improved motivations significantly in the experimental group and most of the students have positive attitudes towards English learning. Considering the students' responses in experimental group, it was clear that they increasingly motivated.

All the findings from the data collection support that both the teachers and learners are benefitted from different audio-visual materials in language achievement. The discussion in the table exactly shows that there was high variation among the performance of the students of experimental groups and improved students' motivation for learning. Audio-visual materials method stimulated thinking of students in EFL classroom. This has been proved through the descriptive analysis. Based on the results, it concluded that there was a significant difference between the mean scores of two groups on the post test. The audio-visual group performed better on post test than the control group did. Therefore, it concluded that the null-hypothesis which was "audio-visual materials have no significant effect on Iranian second grade high school students' language achievement" was rejected, this rejection means that the utilized treatment of the study affected the outcome, so, putting emphasis on the effectiveness of the using audio-visual materials. It also concluded that there was a significant difference between the mean scores of two groups considering motivation. So, it concluded that the null-hypothesis which was "audio-visual materials have no any significant effect on improving Iranian second grade high school students' motivation" was rejected, putting emphasis on the effectiveness of the audio-visual materials. Students develop and increase their understanding 
of learning when they experience a successful and pleasant learning in the EFL classroom. Students find these materials and resources useful in understanding difficult concepts given in the course books.

\section{References}

[1] Bachman, L. F, \& Palmer, A. S. (1996). Language testing in practice. Oxford: Oxford University Press.

[2] Bernaus, M. \& Gardner, R.C. (2008). Teacher motivation strategies, student perceptions, student motivation, and English achievement. The Modern Language Journal, 92(3), 387-401.

[3] Clement, R., Dornyei, Z., \& Noels, K. A. (1994). Motivation, self-confidence, and group cohesion in the foreign-language classroom. Journal of Language Learning, 44(3), 417-448. doi: 10, 1111/j. 1540-4781. 2008. 00753.x

[4] De Bot, K., Lowie, W., \& Verspoor, M. (2005). Second language acquisition: An advanced resource book. London: Routledge.

[5] Dehghani., A. , \& Jowkar., M. (2012). The Impact of Computer-Video Projector on EFL Learners' Learning Listening Comprehension. Academic Research International,3(1), 14-26.

[6] Erfani, M., Iranmehr, A., \& Davari, H. (2011). Deepening ESP reading comprehension through visualization. Journal of Language Teaching and Research, 2(1), 270-273.

[7] Freeman, D. L. (2000). Techniques and principles in language teaching. New York: Oxford University Press.

[8] Gardner, R.C. (1983). Learning another language: A true Social Psychological Experiment. Journal of Language and Social Psychology, 2, 219-239.

[9] Gardner, R.C. (1985). The Role of Attitudes and Motivation. London: Edward.

[10] Gardner, R.C. (1985). Social Psychology in Second Language Learning. Edward Arnold Ltd, London, Great Britain.

[11] Gredler, M. E. (2001). Learning and instruction: Theory into practice (4thed.). Prentice-Hall, Inc., Upper Saddle River, New Jersey.

[12] Gruba, P. (1997). The use of video media in listening assessment. System, 25(3), 335-345.
[13] Hamidi, H., \& Montazeri, M. (2014). Dictionary of second language acquisition. Retrieved March 10, 2015, from http://www.iranelt.com/index.php/introduction-to-sla.

[14] Hemei, J. (1997), Teaching with Video in an English Class, Journal of English Teaching Forum, 35(2), 45-47.

[15] Ismaili, M. (2013). The effectiveness of using movies in the EFL classroom: A study at South East European University. Academic Journal of Interdisciplinary Studies, 2(4), 121-132.

[16] Jafarpour, A. (1992). A course in language testing. Payam Noor University press.

[17] Maftoon, P., Sarem, S. N., \& Hamidi, H. (2012). A closer look at different aspects of language teaching/learning and learner identity. Theory and Practice in Language Studies, 2 (6), 1160-1167.

[18] Mayer, R. E. (2003). The promise of multimedia learning: Using the same instructional design methods across different media. Learning and Instruction, 13, 125-139.

[19] Miller, J. (2009). Teacher identity. In A. Burns \&J. C. Richards (Eds.), Second language teacher education (pp. 172-181). New York: Cambridge University Press.

[20] Mutar, S. S. (2009). The effect of using technical audio-visual aids on learning technical English language at technical institute. Misan Journal of Academic Studies, 8(15), 1-12.

[21] Naraghizadeh, M., \& Barimani, S. (2013). The effect of Call on the Vocabulary Learning of Iranian EFL Learners. Journal of Academic and Applied Studies, 3 (8), 1-12

[22] Nunan, David. (1999). Second language learning and teaching. Boston.

[23] Potosi, A., Jhoana, L., Loaiza, G., Andres, E., Garcia, L., \& Catalina, A.(2009).Using video materials as a teaching strategy for listening comprehension. Universidad Tecnológica dePereira.

[24] Richards, J. C., \& Rodgers, T. S. (1986). Approaches and methods in language teaching. New York: Cambridge University Press.

[25] Safarali, k. S. \& Hamidi, H. (2012). The impact of videos presenting speakers' gestures and facial clues on Iranian EFL learners' listening comprehension. International Journal of Applied Linguistics \& English Literature, 1(6), 106-114. doi:10.7575/ijalel.v.1n.6p.106. 